\title{
Business Characteristics as a Determinant of MSE Growth
}

\author{
Alemu KS* \\ Lecturer and Researcher, Ambo University, Ethiopia
}

\begin{abstract}
The research study evaluated the business characteristics with a view to identify business characteristics that result in fast growth of MSE. Primary data, through structured questionnaire, were collected from the samples of 99 MSEs randomly selected from Addis ketema and Areda sub city. Data were analyzed using both descriptive and inferential statistics with the help of SPSS. By using this software, analysis of variance was carried out to examine the variation in the growth of MSEs related to the variation in each of the independent variables. As two dependent variables were used to measure growth in this study, the result of this software shows different statistical result for both of them. The ANOVA and t-test result indicates, there is a significant variation on the growth of MSEs in relation to the variations of type of business, legal status, formal record and competition level if growth is measured using asset growth. If growth is measured using employment growth, the deference in types of business and having formal recording practice brings difference in growth. But the ANOVA and t-test result shows there is no significant difference in growth with respect to the difference in registration with MSE office and age of business whether it is measured with asset or employment growth.
\end{abstract}

Keywords: MSEs; Small firms; Micro enterprises; Entrepreneurship; Ethiopia

\section{Introduction}

In all successful economies, small enterprises are seen as an essential springboard for growth, job creation and social progress. These enterprises have been recognized as the engines through which the growth objectives of developing countries can be achieved. The sector is claimed to be a breeding ground for development of industrial skill and entrepreneurships. In addition, it upgrades indigenous technologies, including exploitation of locally available raw materials with lower capital, flexible to local market conditions and with less requirement of infrastructure development and utilities.

Therefore, in developing countries if growth is to be broad based and employment opportunities are to grow, greater support should be given to those sections of the economy that are able to absorb much of the labour force. But, over the years, some of the MSE have grown extremely large and profitable and on the other hand, many others have failed or have not been as successful as they might have been. It is natural to say that every small business owner starts with high hopes of success, but it is a usual phenomenon that each year firms go out of businesses. Although failure is not the sole reason for enterprises to leave the business, many enterprises do fail each year [1].

Due to the high contribution of micro and small enterprises in all direction to the economy of the country especially developing countries, MSEs have become the favourite of policy makers as it is commonly believed that they are as essential element of industrialization with forward and backward linkages to different sectors in the economy and for the aforementioned reason. However, before changing the policy, the policy makers themselves should know the factors that influence the growth and expansion of these enterprises.

Despite their potential to improve economic growth, micro and small enterprises (MSEs) in developing countries lack serious attention. They produce largely for the low income group and employ lower levels of techniques. Many of them are self-employed type with a low transformation rate into higher size categories and their innovative activities are limited [2].

Even if many researches are done on this area, currently those things that are responsible for the graduation of those businesses from one level to the next is not clear for researchers and business communities. MSE's growth may be affected by different factors. One of those factors mentioned in different research is business characteristics like the age, size, formality, sector and the like. Ethiopia is not special on this regard that thousands of MSE's are started and abolished soon after a year and some of them will grow fast that even graduate to larger business. Nobody clearly knows what are those business characteristics that result in the growth of some business and death of others.

The purpose of this paper is to explore how business characteristics are responsible for its growth in Ethiopia. An improved knowledge of this linkage may be of considerable utility of policy-makers and any business stake holders. Again this paper adds to the existing store of knowledge by identifying the business characteristics of business that results in growth so that both government and individual business owners will directly apply those characteristics which results in fruitful result. Lastly, it is believed that, in effort to help mushrooming of MSEs, especially by establishing business incubators, academicians can provide consultancy service to MSEs through such researches.

\section{Literature and Hypothesis}

This study aims to fill the gap in the current debate on the characteristics off MSE that result in fast growth. The analysis is based on cross-sectional data of a set of micro and small enterprises in Addis Ababa. This paper explores whether and to what extent growth in MSEs can be explained by those variables. Certain firm characteristics may correlate positively or negatively with MSE growth tendencies. This section explores the relationship between MSE growth and four

*Corresponding author: Alemu KS, Lecturer and Researcher, Ambo University, Ethiopia, Tel: +251913463699; E-mail: kokseyoum@yahoo.com

Received May 17, 2015; Accepted May 27, 2015; Published June 08, 2015

Citation: Alemu KS (2015) Business Characteristics as a Determinant of MSE Growth. Int J Account Res 3: 120. doi:10.4172/2472-114X.1000120

Copyright: ( 2015 Alemu KS. This is an open-access article distributed under the terms of the Creative Commons Attribution License, which permits unrestricted use, distribution, and reproduction in any medium, provided the original author and source are credited. 
widely studied firm-level factors: firm age, legal form, industrial sector, formality and competition.

\section{Firm age and its influence on growth}

The relationship between firm age and growth in the MSE sector is particularly robust. Young MSEs grow substantially more rapidly on average than their older counterparts. Studies in both Africa and Latin America show that young MSEs are more likely to show high rates of growth compared with MSEs that have been in existence longer [3]. A study revealed that the major expansion of dynamic enterprises occurs during their third year of operation [2], and numerous other studies have shown that the average growth rate of firms decreases with age [4].

Why might young MSEs grow more quickly than old MSEs? A seminal theoretical paper by Bridget Hansen [5], offers one possible explanation. Bridget Hansen proposes a learning model in which firm owners discover their efficient sizes of operation gradually. This theory predicts that a firm will expand quickly at first, and then taper off its growth as the firm approaches its optimal size. Notice that while growth slows, productivity is expected to increase as the firm ages and the owner comes to learn the company's optimal size of operations.

In reality, the effect of firm age on productivity is not so clear. On one hand, as they age, firms may benefit from learning by doing, which enables them to develop expertise in production, management, and marketing. Indeed, several recent econometric studies on small firms in the United States show that firm age benefits productivity, even when controlling for firm size [6]. On the other hand, several studies in developing countries suggest that firms suffer productivity losses as they age [7]. Some experts' explanation of such findings is that these firms frequently fail to invest sufficiently in existing or emerging technology, leaving them with relatively outmoded equipment and hindering productivity levels relative to younger firms.

Hypothesis 1: There is significant relationship between the age of the firm and the level of growth attained; firm growth decreases with firm age.

\section{Legal form and its influence on growth}

Businesses can operate under several different legal forms, but the main differentiating factor, as far as growth is concerned, is whether the legal form offers the owners limited liability or not. Previous studies, show that firms with limited liability grow faster than firms with unlimited liability. This is interpreted to imply that limited liability firms' owners are more willing to invest in risky ventures that may foster firm growth [8]. Mcpherson et al. [9] also find that firms with a limited liability are more likely to become insolvent than comparable firms with full liability. But Mervi and Jyrki, [10] suggest that legal form is not a significant factor of growth behaviour.

Mcpherson et al. [11] demonstrate that firms with limited liability have higher growth than firms without limited liability. Several factors could explain the association between limited liability and firm growth. Corporations have the ability to issue stock and their stockholders have the freedom to resell their stock. This ability facilitates the process of raising capital for expansion. Entrepreneurs' expectations also play a role. Their choice of legal form could reflect their assessment of the riskiness of the project undertaken and their incentives for investment and growth [12]. Tax treatment of profits and equity and the liability of the owner under the various legal forms could also affect the entrepreneurs' incentives for investment and growth. Owners of unlimited liability businesses are fully liable with their entire personal assets, while owners of limited liability businesses are only liable up to the amount of their share in the business. The advantage of a limited liability is counterbalanced by increased tax liability and legal complexity. Current profits and equity of unlimited liability businesses are taxed in proportion to the owner's share, while both limited liability businesses earnings and wealth are taxed at the corporate level. The interplay between these two factors could affect investment decisions and thus, growth. Businesses can operate under several different legal forms, but the main differentiating factor, as far as growth is concerned, is whether the legal form offers the owners limited liability or not.

Hypothesis 2: There is significant relationship between the legal status of the firm and the level of growth attained; limited liability firms have higher growth rate than their unlimited liability counterparts.

\section{Industry sector/business type/and its influence on growth}

A significant number of studies carried out to identify the influence of a firms sector on the growth of the firm concur that there are significant differences between sectors in terms of the typical growth rates of the firms. Only a few studies showed that sector variables are not significant $[3,12,13]$. The sector/type of business which a firm is in is likely to be related to investment decisions and competitiveness. The link between the sector and investment decisions or competitiveness is explained by different empirical studies such as those of $[13,14]$ which reveal that firms operating in different sectors differ in terms of their investment decisions and productivity. Previous studies of firm performance have found substantial differences by industry, with small firms in retail and personal service sectors having lower growth rates [15]. This empirical observation could reflect differences in production technologies inherent in specific industries that have an impact on the determination of the "optimal size" of the firm. Thus, surviving businesses in industries characterized by a high degree of economies of scale are expected to exhibit higher rates of growth than surviving firms in industries where scale economies are relatively unimportant [16]. In retail and personal services, start-up barriers may be lower and more intense competitive pressures may characterize these sectors. In addition, products or services in these sectors may be easily imitated. In contrast, participation in industrial businesses or professional services may be highly dependent on very specific sets of capabilities or requirements developed through prior experience or education that render imitation difficult.

Hypothesis 3: There is significant relationship between a firm's sector and the level of growth attained.

\section{Formality}

The degree of MSE formality is another area of focus in the literature. Different researchers have taken different standing point concerning formality. To capture this characteristic, some of the researchers like Juan S. Federico [15] recommend that the business formality variable is constructed from items that measured whether the business was registered with the government and another group of researchers like McPherson et al. [9] recommend for the measurement of this variable as what bookkeeping practices it followed. There are reasons to expect that the degree to which a business is formal may affect its growth. The literature shows that formality has a strong, positive effect on growth $[3,9]$. Businesses that are registered grow more rapidly than the unregistered, and those that keep books also tend to have better growth prospects. These businesses may be better positioned to take advantage of growth opportunities by borrowing against future revenue and may be able to advertise more extensively than informal MSEs. According 
to Rahel Wasihun, [17] formalization increases business legitimacy and reputation in the eyes of their customers. While microenterprises are generally considered part of the informal economy, it is also true that microenterprises may vary considerably across a dimension of informality-formality.

Hypothesis 4: There would be a positive relationship between enterprise formality and its growth. Registered business have higher growth rate than unregistered business

Hypothesis 5: There is significant relationship between formality of the firm and the level of growth attained; firm having financial record have higher growth rate than firms without financial records.

\section{Competition}

Previous research affirms that market characteristics affect venture growth perspectives [18]. In particular, in the case of young MSEs one of the key features of markets refers to the level of competition, which could be described by the number of the main competitors. It is generally acknowledged that the larger the number of competitors is, the higher the competitive pressure would be, affecting negatively the growth perspectives of young MSEs [19]. However, some empirical evidence shows that on the contrary, those firms facing large number of competitor's exhibit higher growth levels [20].

Some arguments explaining this result pointed out that the negative side-effect of competitors may impact principally young MSE survival perspectives, instead of their growth level. In fact, those young firms that survive this intense competition, usually exhibit significant growth levels. Moreover, growth-oriented entrepreneurs would tend to target market segments with a higher level of competition, because of their attractiveness (e.g. differentiation advantages, profitability).

Hypothesis 6: Those firms facing high competition exhibit a higher venture growth.

\section{Methodology}

The aim of this research is to explore the characteristics of growing MSE. Utilizing a self-administered questionnaire, data were collected from two sub-cities of Addis Ababa, where a large number of MSEs are located, namely: Addis ketema sub-city and Arada sub-city. The sample for this survey consisted of 99 MSE. Questionnaires are good research methods as they yield information about the past and present and offer the best means of obtaining standardized stimuli [4].

The data collected from the self-administered questionnaire were analyzed by using descriptive statistics based mainly on frequency distribution and percentage value. In addition, ANOVA test and t-test were used to check the relation between dependent and independent variables. The ANOVA test is used when there are more than two alternatives. The t-test is used for variables having two alternatives to check whether their difference brings difference in the dependent variables.

In measuring growth, although theoretically alternative measurement tools such as growth rate of sales or profits could give more precise results, in practice they are not as credible as the employment and asset growth measure because of entrepreneurs' hesitation to report the true values of their sales and profits. This hesitation, which leads to measurement errors, makes the employment and asset-based measure preferable in studies considering enterprise growth. Again, employment growth is relatively easy for respondents to remember and that is uncontaminated by price changes. Moreover, job creation may be an important social goal, and policies to support MSE's are frequently justified on their supposed employment effects. But the use of employment or asset criteria could also depend on the sector under study. For highly capitalized firms, such as those belonging to certain manufacturing sub-sectors, variation in assets would be a more accurate measure of growth than variation in the workforce. But, this criterion cannot be used in the service sector, which is more labourintensive. Therefore, this paper used both employment and asset growth as a growth measure. Employment Growth is the difference between average employment at inception and current average employment; whereas total asset growth is the difference between the total asset at the current and total asset at the beginning plus unpaid amount of debt.

\section{Findings from the Research}

The study sample consisted of 99 MSEs in which large numbers of them are participated in contraction type of business. This is because of the fact that; the country is under massive contraction. In both government and private sector large building is erecting to change the war future of the country so that the millennium development goal will be attained. Even currently the country is undertaking the large renaissance dam which is the first in Africa both in size and capacity to generate electricity. This proofs that the country is under intense contraction in all area like road, irrigation, building etc. and initiates the interest of many MSEs towards contraction type of business. Therefore, it is perhaps not surprising to see more number of MSE in construction type of business.

\section{Employment growth (asset growth) with respect to type of business engaged in report}

As it is indicated in the Table $1 \mathrm{a}$, from the total sample taken 11 enterprises are engaged in agricultural sector which is actually the back bone of the country's economy. When we look at the growth of those enterprises in this sector category on average they show asset growth of 25,036 and employment growth of 2.64 from the time of establishment to to-date.

The other 18 MSEs in this study are engaged in a manufacturing industry which is the promising sector of economy in bringing large industrial development. The growth of MSEs under this sector category in terms of average asset growth is about 300,255 and employment growth is 4.56 from the year they have been established to to-date.

The other 21 SMEs in this study are engaged in a trade industry which is mostly participating in buying and selling goods and services without changing their form. The growth of MSEs under this sector

\begin{tabular}{|l|l|c|c|}
\hline \multicolumn{5}{|c|}{ Report } \\
\hline Type of business engaged in & asset growth & Employment growth \\
\hline agriculture & Mean & 25036.36 & 2.64 \\
\hline manufacturing & $\mathrm{N}$ & 11 & 11 \\
\hline trade & Mean & 300255.56 & 4.56 \\
\cline { 2 - 4 } & $\mathrm{N}$ & 18 & 18 \\
\hline construction & Mean & 31415.24 & -.57 \\
\cline { 2 - 4 } & $\mathrm{N}$ & 21 & 21 \\
\hline service & Mean & 340228.71 & 6.54 \\
\hline Total & $\mathrm{N}$ & 28 & 28 \\
\hline & Mean & 37590.48 & 3.38 \\
\hline & $\mathrm{N}$ & 21 & 21 \\
\hline & Mean & 168237.62 & 3.57 \\
\hline
\end{tabular}

Table 1a: SME growth with respect to type of business. 
category in terms of average asset growth is about 31,415 and in terms of employment growth is -57 during their operation.

From the fourth category, which is the construction industry, 28 MSEs are included in this study. They are the building block of the country's construction sector which is actually on the infant stage. The performance of MSEs under this sector category in terms of average asset growth is about 340,228 and employment growth is 6.54 during their life time.

The rest 21 enterprises have engaged in a services sector which is believed to be the modern best industry having many bases including tourism, the smokeless industry. The performance of MSEs under this sector category in terms of average asset growth is about 37,590 and employment growth is 3.38 during their operation.

Over all, the above descriptive statistics result shows that, the rate of growth of MSE is also influenced by the sector in which it operates. In total, MSEs in manufacturing and construction sector were more likely to grow than those in trading. Again, the specific sectors that were most likely to generate new jobs through expansion is construction and manufacturing. This is because, the country is under fast construction and the governments need manufacturing sector as they help the country to save hard currency. The gross transformation plan (GTP) is expanding the construction site and many of the individuals are participating in this sector. Again as the government needs to transform these small manufacturing industries to a larger manufacturing industry the country is providing many pulling policies in order to attract investors on the area. Once more, as there is no large manufacturing industry in this country, those small manufacturing industries have high chance of selling their product at good price that will help them for future expansion. The negative sign showed in employment growth of trade shows that, the total number of employees of many trade businesses is less when compared with their past employee level. That means the number of employees consumed by those sector is decreasing.

The above ANOVA result in Table $1 \mathrm{~b}$ suggested that the industry by which the SME is classified has a significant bearing on asset/ employment growth $(\mathrm{F}=3.386$ and 10.374, $\mathrm{df}=4,94, \mathrm{P}=0.012$ and 0.000 ). The results of his study showed that industry is a factor for asset/ employee growth. This variable has a significant bearing in bringing difference in asset/employment growth. This result of ANOVA test shows that the industrial sector has a significant (at the 5\% level) impact on growth. It suggests us sector of the businesses will determine business growth which means that sectoral difference is significant for asset and employee growth. Those who participate on manufacturing and construction industry have high chance of growth than other sectors.

The above result insist us to accept the hypothesis which states that, there is a significant difference on the growth of MSEs in relation to the difference in business type. Difference in the type of business is the result of the difference in the growth of the business.

To sum up the ANOVA result supports the argument; type of business is a factor in the growth of business which means that participating in different type of business brings difference on the growth of MSE.

\section{Employment growth (asset growth) with respect to age of business}

The other variable of this study which is expected to have relation to the growth of MSEs is the age of the business which is the number of years since establishment.

As it is indicated in the above Table $2 \mathrm{a}$, from the total sample enterprises in this study, 52 MSEs have the operation year of less than 5. They are included under the younger part of MSE categories. Looking to the growth of the enterprises that have an operation year of less than 5, using asset and employment growth of the enterprises as a measure of performance, on average these enterprises show 158,371 growth in asset and 4.10 growth in employee from the year they have established to to-date.

Again the same table, shows that, 32 MSEs included in the study have a service life of between 5 to 10 years in which most of MSEs registered with micro and small enterprise office is included, because of the fact that, MSE office establishment is a recent phenomenon. Looking to the growth of the enterprises that have an operation year of between 5 to 10 using asset and employment of the enterprises as a measure of growth, on average these enterprises show 225,365 growth in asset and 2.28 growth in employment from the year they have established to to-date.

On the other hand 11 enterprises in the sample taken for the study have the operation year of 10 to 20 in which most of those businesses established after the privatization policy of this government are included. In terms of growth using asset and employment as a measure, enterprises within the age range of 10 to 20 have an average asset growth of 72,590 and average employment growth of 3.18 during their life time.

The remaining 4 enterprises in the sample for the study have an operation life time of greater than 20 which is actually the oldest part of the whole. The growth of the enterprises in this age category in terms of average asset growth is about 102,500 and employment growth is 8 during their life time.

The overall result shows that large percentage of average asset growth is within the range of 5-10 years followed by those below 5 years. This result shows there is an inverse relationship between enterprise growth

\begin{tabular}{|c|c|c|c|c|c|c|c|}
\hline \multicolumn{8}{|c|}{ ANOVA Table } \\
\hline & & & $\begin{array}{l}\text { Sum of } \\
\text { Squares }\end{array}$ & Df & Mean Square & $\mathbf{F}$ & Sig. \\
\hline \multirow[t]{3}{*}{ Employment growth type of business engaged in } & $\begin{array}{l}\text { Between } \\
\text { Groups }\end{array}$ & (Combined) & 634.274 & 4 & 158.568 & 3.386 & .012 \\
\hline & \multicolumn{2}{|c|}{ Within Groups } & 4402.049 & 94 & 46.830 & & \\
\hline & \multicolumn{2}{|l|}{ Total } & 5036.323 & 98 & & & \\
\hline \multirow[t]{3}{*}{ asset growth type of business engaged in } & $\begin{array}{l}\text { Between } \\
\text { Groups }\end{array}$ & (Combined) & 2.119E12 & 4 & $5.298 \mathrm{E} 11$ & 10.374 & .000 \\
\hline & \multicolumn{2}{|c|}{ Within Groups } & $4.800 \mathrm{E} 12$ & 94 & 5.107E10 & & \\
\hline & \multicolumn{2}{|l|}{ Total } & 6.919E12 & 98 & & & \\
\hline
\end{tabular}

Table 1b: SME growth with respect to type of business. 
and the age of the MSE. The analysis indicates that younger MSEs are likely to show higher rates of growth, compared to those that had been in existence for a longer period. That is to mean that younger firms have high probability of growth. This is mostly related with quality of their product. Most of the time when business men open a business, they attract customer by using different attracting things like may be quality product with less price. But as it grows older they doesn't care that much. Some experts' explanation of such findings is that older firms frequently fail to invest sufficiently in existing or emerging technology, leaving them with relatively outmoded equipment and hindering productivity levels relative to younger firms. Again it is related with the size of the enterprises in which younger firms have small size and make possible the easy and sufficient management which leads to high asset growth. But, concerning the employment level; business with the age of greater than 20 years; have a good performance than the others followed by business with less than five years. This may be because of the size effect that the older business is large in size and should hire more employees than the others.

Most obvious, in terms of interpretation of the results in the above Table $2 \mathrm{~b}$, there is insignificant relation between asset/employment growth and age of SMEs. Even if the asset growth is higher for young businesses and employment growth is high for older businesses, it is not statistically significant $(\mathrm{F}=.957$ and $1.076, \mathrm{df}=3,95, \mathrm{P}=.417$ and .363). This show that age of business does not have a significant effect on business growth. These results refute the Jovanovic model of firm growth, which says younger firms grow faster.

This statistical result supports us to reject the hypothesis of the study which states that, there is a significant difference on the growth of MSEs in relation to the difference in their age range whether the growth is measured by asset or employment growth. But even if there is no statistically different result concerning growth between MSEs in different age group, young enterprises have high asset growth than the

\begin{tabular}{|l|c|c|c|}
\hline \multicolumn{2}{|c|}{ Report } \\
\hline \multicolumn{2}{|l|}{ Age of business } & Asset growth & $\begin{array}{c}\text { Employment } \\
\text { growth }\end{array}$ \\
\hline less than 5 & Mean & $158,371.54$ & 4.10 \\
\cline { 2 - 4 } & $\mathrm{N}$ & 52 & 52 \\
\hline greater or equal to 5 and less than 10 & Mean & $225,365.75$ & 2.28 \\
\cline { 2 - 4 } & $\mathrm{N}$ & 32 & 32 \\
\hline greater or equal to 10 and less than 20 & Mean & $72,590.91$ & 3.18 \\
\hline & $\mathrm{N}$ & 11 & 11 \\
\hline greater than or equal to 20 & Mean & $102,500.00$ & 8.00 \\
\hline Total & $\mathrm{N}$ & 4 & 4 \\
\hline & Mean & 168237.62 & 3.57 \\
\hline
\end{tabular}

Table 2a: SME growth with respect to age of the business. older one and older business have a high employment growth than the younger business. But those differences are not statistically different for MSEs with different age group.

In total the ANOVA result does not support the argument, being in different age group will bring difference in growth of MSE. So age of the business is not the determinants of growth whether it is measured by using asset or employment growth in Addis Ababa.

\section{Employment/growth asset growth/with respect to legal sta- tus of the business}

Another variable to be expected to have a relation with MSE growth that has been included in this study is the legal status of the MSE.

As it is indicated in the above Table $3 \mathrm{a}$, from the total sample enterprises in this study, 56 MSEs are within the category of unlimited liability which means that they are responsible for any unpaid debt and their personal property will be ceased if the debt is not fulfilled. Looking to the growth performance of the enterprises by using asset and employment as a growth measurement, those enterprises with the category of unlimited liability have an average asset growth of 110,242 and employment growth of 3.43 during their life time of operation.

The remaining 43 enterprises in the sample taken for the study are included within the category of limited liability which means they are not personally responsible for any unpaid debt and their debt is limited to what they have invested in the enterprises. In terms of growth using asset and employment as a measure, enterprises with a limited liability status have an average asset growth of 243,766 and employment growth of 3.74 during their life time.

The overall picture of the descriptive statistics result about enterprises performance and their legal status shows that, those enterprises with a limited liability status performs better in terms of asset and employment growth when compared with those enterprises with unlimited liability. The possible justification for this is, due to the fact that those businesses have high chance of borrowing from external sources and expand their business. They can take risky businesses that have a high return due to their limited liability.

The above ANOVA test result in Table $3 \mathrm{~b}$ shows that statistically there is a significant relation between the legal status of the business and its asset growth $(\mathrm{F}=.047, \mathrm{df}=97, \mathrm{P}=.012)$. This means that enterprises with a limited liability have high asset growth. But as the above table result shows there is insignificant difference in employment growth with respect to legal status difference in MSE ( $\mathrm{F}=0.047, \mathrm{df}=97, \mathrm{sig}=0.829)$. Legal status does not have any effect on employment growth. Being a limited liability does not contribute anything to employment growth.

Thus the ANOVA result helps to accept the hypothesis which states that, there is a significant difference in the growth of MSEs in

\begin{tabular}{|c|c|c|c|c|c|c|c|}
\hline \multicolumn{8}{|c|}{ ANOVA Table } \\
\hline & & & $\begin{array}{l}\text { Sum of } \\
\text { Squares }\end{array}$ & Df & Mean Square & $\mathbf{F}$ & Sig. \\
\hline \multirow[t]{3}{*}{ Employment growth type of business engaged in } & $\begin{array}{l}\text { Between } \\
\text { Groups }\end{array}$ & (Combined) & 147.699 & 3 & 49.233 & .957 & .417 \\
\hline & \multicolumn{2}{|c|}{ Within Groups } & 4888.624 & 95 & 51.459 & & \\
\hline & \multicolumn{2}{|c|}{ Total } & 5036.323 & 98 & & & \\
\hline \multirow[t]{3}{*}{ asset growth type of business engaged in } & $\begin{array}{c}\text { Between } \\
\text { Groups }\end{array}$ & (Combined) & 2.274E11 & 3 & $7.580 \mathrm{E} 10$ & 1.076 & .363 \\
\hline & \multicolumn{2}{|c|}{ Within Groups } & 6.692E12 & 95 & 7.044E10 & & \\
\hline & \multicolumn{2}{|c|}{ Total } & 6.919E12 & 98 & & & \\
\hline
\end{tabular}

Table 2b: SME growth with respect to age of the business. 
relation to deference in the legal status if the growth is measured by using asset growth. But the ANOVA results shows there is insignificant difference in growth and reject the hypothesis if growth is measured by using employment growth. This does not mean that there is no effect on employment growth. Even if statistically insignificant difference in growth of employment, there is a difference in the mean employment growth of the two.

Summing up the ANOVA result does show legal status is the determinants of MSE growth if growth is measured by asset growth and not the determinants of growth if growth is measured by using employment as a measurement.

\section{Employment growth/asset growth/with respect to having formal records}

Use of formal record keeping for control in the enterprises day to day business operation is considered as another variable that would result difference in asset growth between those use the system and those do not use.

As it is listed in the Table $4 \mathrm{a}$ above from the total sample enterprises considered in this study, 49 enterprises do not use any kind of formal record keeping as control of its day to day operation. When we look at the growth of enterprises in this category in terms of asset and employment, on average they have shown asset growth of $2.28^{\star} 10^{4}$ and employment growth of 0.80 during their life time.

The remaining 50 sample enterprises included in this study use record keeping for control to facilitate their day to day business activities. In terms of their growth performance in asset and employment, enterprises under this category have an average asset growth of $3.11^{\star} 10^{5}$ and employment growth of 6.28 during their life time.

In general, the average growth of those enterprises using record keeping during their service life has better performance of asset and employment growth when compared with non-users. The possible reason for this is having financial record will provide them with some opportunities to check their status and they can have an opportunity to determine the best price as they exactly know their cost which means their operation is not by chance.

Based on the above SPSS-generated results, Table $4 \mathrm{~b}$ there is a significant difference between the asset/employment growth of MSE having a financial record mechanism and those without it. The result is statistically significant showing business with financial record have high growth rate $(\mathrm{t}=4.101$ and $6.393, \mathrm{df}=97, \mathrm{P}=0.000$ and 0.000$)$.

This t-test result enables to accept the hypothesis which states that, there is a significant difference on the growth of MSEs in relation to the difference in financial record. That means formal financial record will bring difference in the growth of MSE.

Looking in to the above table result, formal record is a determinant of MSE growth whether it is measured by using asset or employment growth. MSEs that have a formal financial record have different growth when compared with those without formal financial record.

\section{Employment growth/asset growth/with respect to competi- tion in the market}

As it is indicated in the above Table $5 \mathrm{a}$, from the total sample taken 13 enterprises are found in high competition markets which demonstrate that there is large number of the same business found

\begin{tabular}{|c|c|c|c|}
\hline \multicolumn{4}{|c|}{ Report } \\
\hline \multicolumn{2}{|c|}{ Legal status of the business } & Asset growth & Employment growth \\
\hline \multirow[t]{2}{*}{ unlimited liability } & Mean & 110242.32 & 3.43 \\
\hline & $\mathrm{N}$ & 56 & 56 \\
\hline \multirow[t]{2}{*}{ limited liability } & Mean & 243766.37 & 3.74 \\
\hline & $\mathrm{N}$ & 43 & 43 \\
\hline \multirow[t]{2}{*}{ Total } & Mean & 168237.62 & 3.57 \\
\hline & $\mathrm{N}$ & 99 & 99 \\
\hline
\end{tabular}

Table 3a: SME growth with respect to legal status of the business.

\begin{tabular}{|c|c|c|c|c|c|c|c|}
\hline \multicolumn{8}{|c|}{ ANOVA Table } \\
\hline & & & $\begin{array}{l}\text { Sum of } \\
\text { Squares }\end{array}$ & Df & Mean Square & $\mathbf{F}$ & Sig. \\
\hline \multirow[t]{3}{*}{ Employment growth type of business engaged in } & $\begin{array}{l}\text { Between } \\
\text { Groups }\end{array}$ & (Combined) & 4.337E11 & 1 & 4.337E11 & 6.486 & .012 \\
\hline & \multicolumn{2}{|c|}{ Within Groups } & $6.486 \mathrm{E} 12$ & 97 & 6.686E10 & & \\
\hline & \multicolumn{2}{|l|}{ Total } & 6.919E12 & 98 & & & \\
\hline \multirow[t]{3}{*}{ asset growth type of business engaged in } & $\begin{array}{l}\text { Between } \\
\text { Groups }\end{array}$ & (Combined) & 2.423 & 1 & 2.423 & .047 & .829 \\
\hline & \multicolumn{2}{|c|}{ Within Groups } & 5033.900 & 97 & 51.896 & & \\
\hline & \multicolumn{2}{|l|}{ Total } & 5036.323 & 98 & & & \\
\hline
\end{tabular}

Table 3b: MSE growth with respect to legal status of the business.

\begin{tabular}{|c|c|c|c|c|c|}
\hline \multicolumn{6}{|c|}{ Group Statistics } \\
\hline & financial record & $\mathbf{N}$ & Mean & Std. Deviation & Std. Error Mean \\
\hline \multirow[t]{2}{*}{ Employment growth } & Yes & 50 & 6.28 & 8.028 & 1.135 \\
\hline & No & 49 & .80 & 4.860 & .694 \\
\hline \multirow[t]{2}{*}{ asset growth } & Yes & 50 & 3.11E5 & 313700.381 & 44363.933 \\
\hline & No & 49 & $2.28 \mathrm{E} 4$ & 31052.103 & 4436.015 \\
\hline
\end{tabular}

Table 4a: SME growth with respect to having formal record. 


\begin{tabular}{|c|c|c|c|c|c|c|c|c|}
\hline & & \multicolumn{7}{|c|}{ t-test for Equality of Means } \\
\hline & & \multirow[t]{2}{*}{$T$} & \multirow[t]{2}{*}{ Df } & \multirow[t]{2}{*}{ Sig. (2-tailed) } & \multirow[t]{2}{*}{$\begin{array}{c}\text { Mean } \\
\text { Difference }\end{array}$} & \multirow[t]{2}{*}{$\begin{array}{l}\text { Std. Error } \\
\text { Difference }\end{array}$} & \multicolumn{2}{|c|}{$\begin{array}{l}95 \% \text { Confidence Interval of } \\
\text { the Difference }\end{array}$} \\
\hline & & & & & & & Lower & Upper \\
\hline \multirow[t]{2}{*}{ Employment growth } & Equal variances assumed & 4.101 & 97 & .000 & 5.484 & 1.337 & 2.830 & 8.138 \\
\hline & Equal variances not assumed & 4.121 & 80.949 & .000 & 5.484 & 1.331 & 2.836 & 8.132 \\
\hline \multirow[t]{2}{*}{ asset growth } & Equal variances assumed & 6.393 & 97 & .000 & 287888.896 & 45033.540 & 198509.784 & 377268.008 \\
\hline & Equal variances not assumed & 6.457 & 49.980 & .000 & 287888.896 & 44585.163 & 198336.056 & 377441.737 \\
\hline
\end{tabular}

Table 4b: SME growth with respect to having formal record.

\begin{tabular}{|c|c|c|c|}
\hline \multicolumn{4}{|c|}{ Report } \\
\hline \multicolumn{2}{|c|}{ Competition in the market } & Asset growth & Employment growth \\
\hline \multirow[t]{2}{*}{ very high } & Mean & $243,707.69$ & 3.00 \\
\hline & $\mathrm{N}$ & 13 & 13 \\
\hline \multirow[t]{2}{*}{ high } & Mean & $231,132.06$ & 5.25 \\
\hline & $\mathrm{N}$ & 36 & 36 \\
\hline \multirow[t]{2}{*}{ normal } & Mean & $199,157.06$ & 3.35 \\
\hline & $\mathrm{N}$ & 17 & 17 \\
\hline \multirow[t]{2}{*}{ low } & Mean & $25,088.24$ & 2.12 \\
\hline & $\mathrm{N}$ & 17 & 17 \\
\hline \multirow[t]{2}{*}{ very low } & Mean & $84,650.00$ & 2.00 \\
\hline & $\mathrm{N}$ & 16 & 16 \\
\hline \multirow[t]{2}{*}{ Total } & Mean & $168,237.62$ & 3.57 \\
\hline & $\mathrm{N}$ & 99 & 99 \\
\hline
\end{tabular}

Table 5a: MSE growth with respect to competition level.

\begin{tabular}{|c|c|c|c|c|c|c|c|}
\hline \multicolumn{8}{|c|}{ ANOVA Table } \\
\hline & & & $\begin{array}{l}\text { Sum of } \\
\text { Squares }\end{array}$ & Df & Mean Square & $\mathbf{F}$ & Sig. \\
\hline \multirow[t]{3}{*}{ Employment growth competition in the market } & Between Groups & (Combined) & 181.926 & 4 & 45.482 & .881 & .479 \\
\hline & Within Groups & & 4854.397 & 94 & 51.643 & & \\
\hline & Total & & 5036.323 & 98 & & & \\
\hline \multirow[t]{3}{*}{ asset growth competition in the market } & Between Groups & (Combined) & $6.929 \mathrm{E} 11$ & 4 & 1.732E11 & 2.615 & .040 \\
\hline & Within Groups & & $6.226 \mathrm{E} 12$ & 94 & $6.624 \mathrm{E} 10$ & & \\
\hline & Total & & $6.919 \mathrm{E} 12$ & 98 & & & \\
\hline
\end{tabular}

Table 5b: MSE growth with respect to competition level.

at their nearby. When we see at the growth of those enterprises functioning in this market category on average they show asset growth of 243,707 and employment growth of 3 during their life time starting from establishment to now.

The other 36 MSEs in this study are functioning in the market where the competition is high which is somewhat less than the first category. The growth of MSEs under this market category in terms of asset and employment shows the average asset growth of about 231,132 and employment growth of 5.25 for their whole operation life time.

The third categories of those enterprises are 17 MSEs which are functioning in the market where competition is normal. In this type of market the competition level is moderate that it is not too high or too low which means medium. When we see the growth of MSEs functioning in this market category where the competition is normal in terms of average asset and employment growth, it is about 199,157 and 3.35 respectively.

The fourth category of those enterprises included in this study is 17 MSEs which are functioning in the market where the competition is low. In this type of market the number of business men found at their nearby are small in number. With regard to the growth of MSEs under this category where the competition is low in terms of average asset and employment growth is 25,088 and 2.12 respectively.
The remaining 16 enterprises are functioning in the market category where there is very low competition. In this types of market the number of other business with similar products are very small. With respect to the growth performance of those businesses dealing with this type of market where the competition is very low in terms of average asset and employment growth is 84,650 and 2 respectively during their operation.

As the Table 5a shows the stiffness of competition have a positive effect on business growth. As the competition increase asset growth also increase.

The possible explanation for the above descriptive statistics result is that, people want to purchase products where there is large number of sellers and this will increase the income of the organization which is responsible for business growth. Due to the existence of many options available where there is large number of business in the market, people want to purchase goods and services from them. The existence of competition again makes those enterprises innovative that may be responsible for the growth of their sales which in turn bring business growth. So market competition have a significant effect on asset growth, which means that firms with highly competitive market are more likely to grow.

The above ANOVA result in Table $5 \mathrm{~b}$ indicates that competition 


\begin{tabular}{|l|c|c|c|c|c|}
\hline \multicolumn{3}{|c|}{} & \multicolumn{3}{|c|}{ Group Statistics } \\
\hline \multirow{2}{*}{ Employment growth } & Registration with MSE office & N & Mean & Std. Deviation & Std. Error Mean \\
\cline { 2 - 5 } & Yes & 58 & 3.34 & 7.979 \\
\hline asset growth & No & 41 & 3.88 & 5.917 \\
\hline & Yes & 58 & $1.27 \mathrm{E} 5$ & 237830.452 \\
\hline
\end{tabular}

Table 6a: MSE growth with respect to their registration.

\begin{tabular}{|c|c|c|c|c|c|c|c|c|}
\hline & & \multicolumn{7}{|c|}{ t-test for Equality of Means } \\
\hline & & \multirow[t]{2}{*}{$\mathbf{t}$} & \multirow[t]{2}{*}{ Df } & \multirow{2}{*}{$\begin{array}{c}\text { Sig. } \\
\text { (2-tailed) }\end{array}$} & \multirow{2}{*}{$\begin{array}{c}\text { Mean } \\
\text { Difference }\end{array}$} & \multirow{2}{*}{$\begin{array}{l}\text { Std. Error } \\
\text { Difference }\end{array}$} & \multicolumn{2}{|c|}{$95 \%$ Confidence Interval of the Difference } \\
\hline & & & & & & & Lower & Upper \\
\hline \multirow[t]{2}{*}{ Employment growth } & Equal variances assumed & -.363 & 97 & .717 & -.533 & 1.469 & -3.449 & 2.383 \\
\hline & Equal variances not assumed & -.382 & 96.747 & .704 & -.533 & 1.397 & -3.306 & 2.240 \\
\hline \multirow[t]{2}{*}{ asset growth } & Equal variances assumed & -1.850 & 97 & .067 & -99066.933 & 53558.833 & -205366.391 & 7232.525 \\
\hline & Equal variances not assumed & -1.784 & 74.379 & .079 & -99066.933 & 55539.865 & -209723.170 & 11589.305 \\
\hline
\end{tabular}

Table 6b: MSE growth with respect to registration with MSE office.

is of importance to the survival of MSE. The result shows there is a significant relation between asset growth and the market in which it operates. The stiffness of competition will determine the business growth $(\mathrm{F}=2.615, \mathrm{df}=4,94, \mathrm{P}=0.040)$. With respect to employment, the competition in which the business functions does not have an effect on employment growth. The result shows employment growth in different market is statistically insignificant $(\mathrm{F}=.881, \mathrm{df}=4,94, \mathrm{P}=$ .479). Irrespective of the market in which the business function the employment growth is not affected.

Thus the ANOVA result helps to accept the hypothesis which states that, there is a significant difference on growth of MSEs in relation to the level of competition in the market if the growth is measured by using asset growth. But as there is insignificant relation between employment growth and level of competition in the market, this hypothesis is rejected if growth is measured by using employment growth. Which means difference in competition level in market does not bring difference in growth if, it is measured by using employment growth. But this does not mean that there is no difference in employment growth among different level of market with different competition. As has been stated before average employment growth is high with high level of competition.

Generally the ANOVA result shows market competition is the determinants of growth if growth is measured by using asset growth, otherwise not a determinant, if growth is measured by using employment growth as a measure.

\section{Employment growth/asset growth/with respect to registration with MSE office}

The last variable to be included in this study as a determinant of asset growth is registration with MSE office. That is whether the business has been registered to MSE office or trade and industry office. The business within formal sector should be registered to either of the two office i.e. MSE office or trade and industry.

As it is listed on the above Table 6a, from the total sample enterprises in this study, 58 MSEs are registered to MSE office to be under the umbrella of this office rules and regulation. They can get any special benefits provided by this office to its members. Looking to the growth of the enterprises registered with MSE offices using asset and employment as a performance measurement, on average these enterprises demonstrates an asset growth of $1.27^{\star} 10^{5}$ and employment growth of 3.34 during their operation period.
The remaining 41 enterprises in the sample taken didn't have registered with MSE office. That means they are registered with trade and industry of their respective sub city. Concerning their growth using asset and employment as a measure, enterprises not registered with micro and small enterprises shows an average asset growth of $2.26^{\star} 10^{5}$ and employment growth of 3.88 during their life time. The asset growth for both of them is almost similar and there is no such big difference among the two groups.

Finally, the t-test in Table $6 \mathrm{~b}$ also provides no evidence that formality has an appreciable effect on a firm's employment growth $(t=-363, d f=97, P=.717)$. That is, once we control for the rest of the characteristics of firms as well as other observable factors, formality does not make employment growth any more likely. Even if Formality status increase the growth rate by some amount in principle, this result indicate that the formal registration in this country is not important for employment growth. Again, concerning the asset growth it will become the same of this that formality has insignificant effect on business growth $(\mathrm{t}=1.85, \mathrm{df}=97, \mathrm{P}=0.067)$.

Hence the hypothesis of the study which states that, there is a significant difference on the growth of MSEs in relation to their formality is rejected irrespective of the measurement change. Meaning that there is no difference in growth of those businesses registered with MSE office and those registered with trade and industry whether it is measured by using asset or employment.

To conclude this t-test result, the formality of MSE is not the determinant of growth, which means that there is no growth difference of MSE with respect to the difference in the formality status.

\section{Conclusions}

This study investigates the characteristics of business that result in growth. The data set provides an excellent opportunity for investigating the effects of business characteristics on firm growth. While some of the findings support commonly held beliefs, others suggest that some popular concepts regarding small business growth may need to be re-examined. The study supports the idea that, there is a significant variation in the growth of MSEs with respect to type of business, legal status, having formal record keeping practice, legal form and competition level in the market if asset is used as a growth measurement. That means the variation in those variables will result in the variation of growth if the measurement of growth is asset growth. But the study shows there is no significant difference between MSE 
growth with respect to the variation in registration with MSE office and age of business whether the growth is measured by using asset growth or employment growth.

The statistical result for the second dependent variable that is employment shows, there is a significant variation in the growth of MSE with respect to type of business and having formal record if growth is measured using employment growth. With respect to this variable, the statistical result shows there is no difference in growth between MSE with respect to the difference in age of the business, legal status and competition.

\section{Recommendation}

Based on the above finding the study forwards the following lessons that may be of use to researchers and policy makers.

Even if registration with MSE office is expected to have a positive relation, the result shows that those enterprises registered with MSE office have less growth rate when compared with those registered with trade and industry. This implies that the effort of this office in making those businesses grow is not effective. So it is better if the MSE office discuss with the participants and other stakeholder to change their way in order to put those businesses on the fast train.

The other is record keeping practices of the enterprises. The result shows those enterprises with formal record keeping practice shows better growth. If that is so, all MSEs should start using a formal record keeping practice. For record keeping again they should have to hire an expert on the area which makes things difficult for them. As a result of their inability to hire a specialist in the area it will be good if stakeholders arrange training that employee themselves can learn and have a record by their own.

\section{References}

1. Abebe T (2011) Analysis of the Success Factors of Micro and Small Business Enterprises in Addis Ababa

2. Ishengoma EK, Kappel R (2008) Business Constraints and Growth Potential of Micro and Small Manufacturing Enterprises in Uganda. GIGA Research Programme: Transformation in the Process of Globalisation.

3. Mead DC, Liedholm C (1998) The Dynamics of Micro and Small Enterprises in Developing Countries. World Development 26: 61-74.

4. Davidsson P, Kirchhoff B, Hatemi JA, Gustavsson H (2002) Empirical Analysis of Employment Growth Factors Using Swedish Data. Journal of Small Business Management 40: 332-349.

5. Hansen B, Hamilton RT (2011) Factors distinguishing small firm growers and non-growers. International Small Business Journal.

6. Bwisa HM, Gathenya JW, Kihoro JM (2011) Interaction between Women Entrepreneurs' Age and Education on Business Dynamics in Small and Medium Enterprises in Kenya. International Journal of Business and Social Science.

7. Papadaki E, Cham B (2002) Growth Determinants of Micro-Businesses in Canada.

8. Jasra JM, Khan MA, Hunjra AI, Rehman RAU, Azam RI (2011) Determinants of business success of small and medium enterprises. International Journal of Business and Social Science 2

9. McPherson MA, Rous JJ (2010) Access to Finance and Small Enterprise Growth: Evidence from East Java. The Journal of Developing Areas 43: 159172.

10. Niskanen M, Niskanen J (2007) The Determinants of Firm Growth in Small and Micro Firms-Evidence on relationship lending effects.

11. McPherson MA, Molina DJ, Jewell RT (2010) The Determinants of the Growth of Microenterprises in Central Mexico: Evidence from a Survey in Toluca. Canadian Journal of Development Studies 31: 209-223.

12. Reid GC, Xu Z (2009) Growth and Survival Determinants of Chinese Private Firms: Fieldwork evidence and econometric.

13. Brown JD, Earle JS, Lup D (2004) What Makes Small Firms Grow? Finance, Human Capital, Technical Assistance, and the Business Environment in Romania. William Davidson Institute.

14. Rachel Doern (2009) Investigating Barriers to SME Growth and Development in Transition Environments. International Small Business Journal 27: 275-305.

15. Federico JS, Kantis H, Rabeti R (2015) Exploring the determinants of young smes'growth: evidence from contrasting regions.

16. Islam MDS (2012) Entrepreneurs' biographic characteristics and small enterprise growth in Bangladesh: an empirical analysis. International Journal of Business and General Management 1: 63-74.

17. Wasihun R, Paul I (2010) Growth determinants of women-operated micro and small enterprises in Addis Ababa. Journal of Sustainable Development in Africa: 12: 233- 246.

18. Qureshi MH, Ayyub S, Ramzan M, Zaman Q, Yasir M (2012) Factors affecting small-business performance in punjab-pakistan: a gender based analysis. Interdisciplinary journal of contemporary research in business 4: 687- 697

19. Doern R (2009) A Critique and Suggestions for Developing the Methodology Institute of Interdisciplinary Business Research.

20. Nichter S, Goldmark L (2005) Understanding micro and small enterprise growth. 